\title{
圧粉磁芯の微視組織および磁気特性に及ぼす 原料鉄粉粒子形状の影響
}

\section{高下拓也 中村尚道尾㟝由紀子}

JFE スチール株式会社スチール研究所

J. Japan Inst. Met. Mater. Vol. 79, No. 6 (2015), pp. 315-323

(C) 2015 The Japan Institute of Metals and Materials

\section{Influence of the Particle Shape on Microstructure and Magnetic Properties of Iron Powder Cores}

Takuya Takashita, Naomichi Nakamura and Yukiko Ozaki

Steel Research Laboratory, JFE Steel Corporation, Chiba 260-0835

The coercive force of an iron powder core decreases with an increase in the circularity of raw iron powder. Microstructural observation reveals that the crystal grain size of the iron powder core is reduced through recrystallization during the stress relief annealing after the powder compaction. An analysis of the work hardening behavior through the compaction process shows that a rounder particle shape leads to a smaller particle deformation, resulting in a reduction of the crystal grain refinement through recrystallization. A grain boundary pinning model well describes the reduction of coercive force with the increase in the eventual grain size. [doi:10.2320/jinstmet.J2015006]

(Received January 21, 2015; Accepted March 27, 2015; Published June 1, 2015)

Keywords: water atomized iron powder, iron powder core, iron loss, particle shape

\section{1. 緒言}

圧粉磁芯とは絶縁被覆を施した軟磁性金属粉末を圧縮成形 して製造される磁芯である. 圧粉磁芯はフェライトなどの酸 化物磁性材料に比べると飽和磁束密度が高く, 電磁鋼板など の金属磁性材料に比べると渦電流損が低い1)ため,これら従 来の磁芯用材料ではカバーできなかった動作磁束密度が高 く, かつ動作周波数が高く低渦電流損が要求される用途(高 速モーターの磁芯, 自動車用リアクトルの磁芯等)への適用 が期待されて抢り，一部で実用化されている22.

圧粉磁芯用の軟磁性金属粉末としては純鉄粉 ${ }^{3)}, \mathrm{Fe}-\mathrm{Si}^{4)}$ および $\mathrm{Fe}-\mathrm{Si}-\mathrm{Al}{ }^{5}$ 等の合金粉末が用いられている。このう ち, 純鉄粉は合金粉末に比べて低コストである。また，圧縮 密度が高いため磁束密度の高い磁芯が得られるという利点が ある. 一方で合金粉末に比べてヒステリシス損失が高いた め, ヒステリシス損失の低減による磁芯の損失低減が要求さ れている.

ヒステリシス損失は保磁力と相関があり ${ }^{6)}$, 保磁力を低減 することでヒステリシス損失を減少させることができる。 ま た，保磁力は金属組織中に存在する結晶粒界，歪，不純物々 いった磁壁の移動を妨げる因子を減らすことで低減される7).

圧粉磁芯は成形後に歪取熱処理を行い, 保磁力を低減して 用いるのが一般的である. 北条ら ${ }^{8)}$ は純鉄系圧粉磁芯の歪取 熱処理について, 熱処理温度の高温化による保磁力の低減が, $973 \mathrm{~K}$ 以上で増大に転じると報告している。この原因を北条
らは熱処理中の再結晶による結晶粒の微細化と考察してい る. また, Maeda ら ${ }^{9)}$ は原料粉末の粒子形状が圧粉磁芯の鉄 損に及ぼす影響について検討しており，鉄粉の球状化により 渦電流損とヒステリシス損が低減されることを報告している.

圧粉磁芯の原料粉末の粒子形状は圧縮成形時における粉末 粒子間の接触点 (応力集中点)の数および分布を支配するた め, 加圧に伴い蓄積される歪量に影響を及ぼすと考えられ る. 成形時に圧粉磁芯に導入された歪は後続の歪取熱処理中 の再結晶挙動に影響を及ぼし, 圧粉磁芯の微細組織を变化さ せる可能性がある.しかしながら, 粉末の粒子形状と成形時 に導入される歪の関係, さらには歪取熱処理前後で変化する 圧粉磁芯中微細組織や，これに関連付けた保磁力への影響に ついて, 定量的な議論はこれまで十分になされていない.

そこで, 本研究では純鉄系圧粉磁芯について, 原料粉末の 粒子形状が圧粉磁芯の微視組織および保磁力に及ぼす影響に ついて定量的検討を行った. その結果, 鉄粉の粒子球状化に より圧粉磁芯の結晶粒径が粗大化し, 保磁力が低減すること を見出した. 本論文ではその詳細と保磁力低減メカニズムに ついて報告する。

\section{2. 原料鉄粉の作製}

\section{1 作製方法}

原料鉄粉は水アトマイズ法によって作製した。粒子形状は 水圧水量等のアトマイズ条件の調整により制御した. 異なる 3 水準の条件でアトマイズされた鉄粉を, いずれも水素中 
$1223 \mathrm{~K}$ で $3.6 \mathrm{ks}$ 間熱処理した後，篩分級で質量平均粒子径 $D_{50}$ が約 $80 \mu \mathrm{m}$ となるように篩を用いて粒度分布を調整し, 原料鉄粉を得た。得られた原料鉄粉に対して, JIS Z 2504 に記載のホールフロー法による見掛密度の測定と, JIS Z 2510 に記載の篩分級により粒度分布を測定し, 質量平均粒 子径 $D_{50}$ の測定を行った. 見掛密度の測定は各原料鉄粉で 3 回実施し, その平均值を用いた。 質量平均粒子径 $D_{50}$ は各粒 度の質量を粒度の小さい順に積算し, その積算質量が総質量 の $50 \%$ になる粒度とした。

上記のようにして得られた原料鉄粉の組織観察を, 光学顕 微鏡を用いて行った. 原料鉄粉のサンプルを熱硬化型の樹脂 に埋込み，鉄粉粒子断面を研磨したのち，ナイタールで腐食 して観察面とした。結晶粒径は上記組織写真から切断法 ${ }^{10)}$ により測定した. 視野数は各 4 視野とし, 4 視野の測定值の 平均值を結晶粒径とした.

また，原料鉄粉断面の円形度を画像解析により計算した。 本検討では以下の式のように円形度 $C$ を定義した。

$$
C=L_{\mathrm{c}} / L_{\mathrm{a}}
$$

ここで $L_{\mathrm{a}}$ は粒子断面の外周, $L_{\mathrm{c}}$ は粒子断面積と同等の面積 を有する真円の外周である. 円形度が 1 に近い粒子ほどそ の断面形状は真円に近いことを示す。なおこの画像解析には Image $\mathrm{J}$ (オープンソース, アメリカ国立衛生研究所)を用い た. 視野数は 4 視野で, 視野中の粒子のうち断面積より求 めた円相当径が $10 \mu \mathrm{m}$ 以上のものの平均值を円形度とした.

さらに, 原料鉄粉の粒子硬度をマイクロビッカース法によ り測定した。測定は上述の組織観察で用いた樹脂埋込サンプ
ルを用い，押込加重 $0.245 \mathrm{~N}$ ，測定点数 5 点とし，最小值と 最大值を除いた 3 点の平均值を硬度とした.

\section{2 原料鉄粉粉体特性}

Table 1 には原料鉄粉 $\mathrm{A}, \mathrm{B}$ 抢よび C の化学成分を示す. 主な不純物は $\mathrm{O}, \mathrm{Si}$ 抢よび $\mathrm{Mn}$ であり, 不純物総量は最も高 い原料鉄粉 B と低い原料鉄粉 C の差が 0.017 mass\%であっ た.この差はアトマイズ条件に起因する不純物元素の歩留の 変動による．のちに議論するように，この不純物量差の保磁 力に対する影響は粒子径状差の影響に比べると十分小さい.

Fig. 1 には腐食を行った原料鉄粉断面の光顕写真を示す. 原料鉄粉 B および C の断面は，不定形であるのに対して， 鉄粉 $\mathrm{A}$ の断面は真円に近い形状であった.

原料鉄粉の粉体特性, 結晶粒径, 硬度および円形度測定結 果を Table 2 にまとめて示す. 平均粒子径 $D_{50}$ および結晶粒 径ついては 3 種類の原料鉄粉でほぼ同一であった。硬度は 最も高い鉄粉 $\mathrm{A}$ が $H v=87$, 最も低い鉄粉 $\mathrm{C}$ が $H v=75$ であ った. 見掛密度は大きく異なって抢り, 最も高い鉄粉 $\mathrm{A}$ は $4.07 \mathrm{Mg} \mathrm{m}^{-3}$, 最も低い鉄粉 $\mathrm{C}$ は $3.19 \mathrm{Mg} \mathrm{m}^{-3}$ であった. 見掛密度と光顕写真より解析した円形度の関係を求めた結果 を Fig. 2 に示す. 粉末の円形度が 1 に近づくとともに見掛 密度が増加することを確認した。

一般に，見掛密度は鉄粉の粒度分布，形状等によって変化 し, 鉄粉が球に近いほど見掛密度は高くなる11). 本論文で 用いた原料鉄粉 $\mathrm{A}, \mathrm{B}$ 抢よび C は粒度分布が同一であるた め, 見掛密度は原料鉄粉の形状に対応するものと考えられ

Table 1 Chemical composition.

(mass\%)

\begin{tabular}{|c|c|c|c|c|c|c|c|c|c|c|c|c|}
\hline $\begin{array}{l}\text { Based iron } \\
\text { powder }\end{array}$ & $\mathrm{C}$ & $\mathrm{O}$ & $\mathrm{N}$ & $\mathrm{Si}$ & $\mathrm{Mn}$ & $\mathrm{P}$ & $\mathrm{S}$ & $\mathrm{Cr}$ & $\mathrm{Ni}$ & $\mathrm{Al}$ & $\mathrm{Fe}$ & $\begin{array}{c}\text { Total } \\
\text { impurity }\end{array}$ \\
\hline $\mathrm{A}$ & 0.0020 & 0.0690 & 0.0005 & 0.0200 & 0.0430 & 0.0090 & 0.0004 & 0.0080 & 0.0090 & 0.0030 & Bal. & 0.164 \\
\hline B & 0.0043 & 0.0673 & 0.0005 & 0.0170 & 0.0400 & 0.0090 & 0.0004 & 0.0080 & 0.0200 & 0.0030 & Bal. & 0.170 \\
\hline $\mathrm{C}$ & 0.0033 & 0.0539 & 0.0010 & $<0.0080$ & 0.0520 & 0.0020 & 0.0002 & 0.0180 & 0.0200 & 0.0030 & Bal. & 0.153 \\
\hline
\end{tabular}

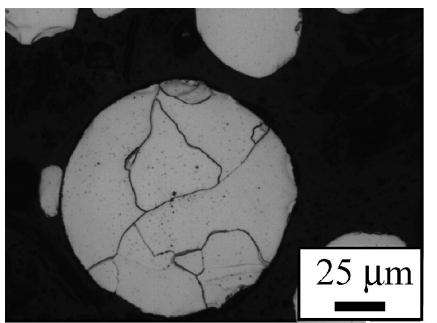

(a) Powder A

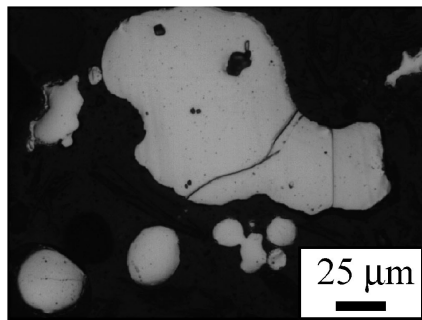

(b) Powder B

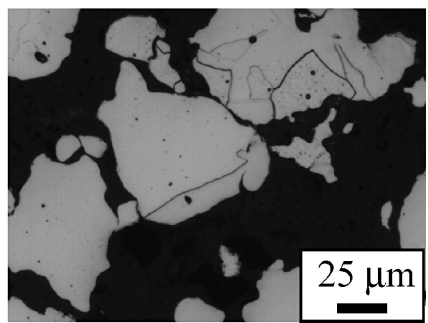

(c) Powder C

Fig. 1 Optical micrographs of the cross section of based powders particles.

Table 2 Powder properties.

\begin{tabular}{|c|c|c|c|c|c|c|c|c|c|c|c|}
\hline \multirow{2}{*}{$\begin{array}{l}\text { Based iron } \\
\text { powder }\end{array}$} & \multirow{2}{*}{$\begin{array}{c}\text { Apparent } \\
\text { density, } \\
A D / \mathrm{Mg} \mathrm{m}^{-3}\end{array}$} & \multicolumn{6}{|c|}{ Particle size distribution (mass\%) } & \multirow{2}{*}{$\begin{array}{c}\text { Mean } \\
\text { diameter, } \\
D_{50} / \mu \mathrm{m}\end{array}$} & \multirow{2}{*}{$\begin{array}{c}\text { Crystal } \\
\text { grain size, } \\
D / \mu \mathrm{m}\end{array}$} & \multirow{2}{*}{$\begin{array}{l}\text { Hardness, } \\
\qquad H v\end{array}$} & \multirow{2}{*}{$\underset{C}{\text { Circularity, }}$} \\
\hline & & $\underset{\mu \mathrm{m}}{180 \sim 150}$ & $\underset{\mu \mathrm{m}}{150 \sim 106}$ & $\begin{array}{c}106 \sim 75 \\
\mu \mathrm{m}\end{array}$ & $\begin{array}{c}75 \sim 63 \\
\mu \mathrm{m}\end{array}$ & $\begin{array}{c}75 \sim 45 \\
\mu \mathrm{m}\end{array}$ & $\underset{\mu \mathrm{m}}{45 \sim}$ & & & & \\
\hline A & 4.07 & 0.6 & 25.0 & 31.8 & 9.8 & 17.4 & 15.4 & 82.2 & 39.7 & 87 & 0.83 \\
\hline $\mathrm{B}$ & 3.57 & 0.1 & 23.5 & 32.8 & 8.4 & 17.2 & 18.0 & 81.0 & 40.5 & 84 & 0.77 \\
\hline $\mathrm{C}$ & 3.19 & 1.3 & 23.1 & 33.6 & 8.6 & 16.8 & 16.6 & 82.4 & 40.7 & 75 & 0.73 \\
\hline
\end{tabular}


る.そこで，以降の検討では原料鉄粉の形状指標として円形 度を用いる。

\section{3. 圧粉磁芯の作製および特性評価方法}

\section{1 圧粉磁芯作製方法}

本研究における圧粉磁心の作製方法を Fig. 3 に示す。 ず，2.1 節で作製した原料鉄粉に対して絶縁処理を行った. シリコーン樹脂(東レダウコーニング社製, SR2400, 密度 $\left.1.048 \mathrm{Mg} \mathrm{m}^{-3}\right)$ をキシレンで 1 mass\%に希釈したシリコー ン樹脂溶液を，原料鉄粉に対して固形分が 0.25 mass \% とな るように混合した．これを室温，大気中でキシレンを揮発さ せる乾燥工程を経て，シリコーン樹脂が粒子表面に被覆され た絶縁被覆鉄粉を得た．乾燥後に樹脂を硬化させる目的で大 気中 $473 \mathrm{~K}$ で $7.2 \mathrm{ks}$ 間の加熱硬化処理を施した。加熱硬化 処理後の絶縁被覆鉄粉を室温, 圧力 $980 \mathrm{MPa}$ で外径 38 $\mathrm{mm}$, 内径 $25 \mathrm{~mm}$, 高さ $6 \mathrm{~mm}$ のリング状に圧縮成形して圧 粉磁芯とした(以後, 本試料を“成形まま磁芯” と記す)。さ らに，圧縮成形時に鉄粉に導入された歪除去のため，大気圧 の窒素雰囲気中で，圧粉磁芯の一般的な歪取熱処理温度の範 囲内8)である， $823 \mathrm{~K}$ で $2.7 \mathrm{ks}$ 間または $973 \mathrm{~K}$ で $2.7 \mathrm{ks}$ 間 の 2 水準の条件で熱処理を施した圧粉磁芯も作製した（以 後，本試料を“熱処理後磁芯”と記す)．作製した圧粉磁芯 は各条件で 1 個ずつである。

\section{2 特性評価方法}

本研究で行った測定項目を，Table 3 に示す。すべての磁 芯について，光学顕微鏡による組織観察とマイクロビッカー ス硬度測定を行った。埋込および腐食は原料鉄粉と同様の方 法で行った． 硬度測定法も原料鉄粉の場合と同様である。こ

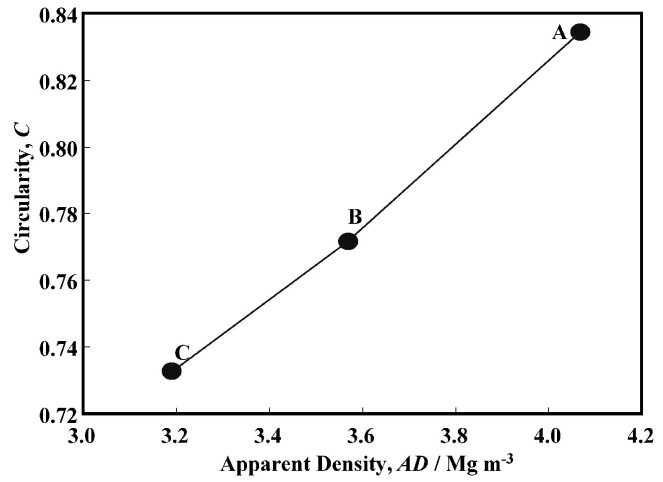

Fig. 2 Relationship between apparent density and circularity of the based iron powder particle.
こで，観察面はリングの直径に沿って分断される軸方向断面 に統一した

それぞれの磁芯について，寸法と質量を測定し，磁路長と 密度を算出した. さらに, 熱処理後磁芯については直流磁化 曲線の測定を行った．巻線は直径 $0.6 \mathrm{~mm}$ の銅ホルマル線を 用い, 1 次側 100 ターン, 2 次側 40 ターンとした。装置は メトロン技研製 SK-110 型を用い，励磁磁束密度は $1.0 \mathrm{~T}$ と した.

磁芯内部の歪分布は，組織観察と同じ観察面で走査型電子 顕微鏡 $(\mathrm{SEM})$ を用いた電子線後方散乱回折法 $(\mathrm{EBSD}$ 法)に よる結晶方位解析 (SEM/EBSD 解析)を行い，カーネル平均 方位差 $(\mathrm{KAM})$ 值を測定面にマッピングすることにより評価 した ${ }^{12)}$. ここで, 解析領域は $500 \mu \mathrm{m} \times 500 \mu \mathrm{m}$ ，解析ステッ プは $1 \mu \mathrm{m}$ で測定した。結晶方位差を表す KAM 值の計算 は，正六角形の画素(カーネル)と隣り合う 6 個のカーネル との結晶方位差平均とし，隣接するカーネル間の方位差が 5 を超える場合は結晶粒界とみなし計算から除外した。した がって，KAM 值が大きい領域ほど歪が大きいとみなすこと ができる. SEM / EBSD 解析に用いた SEM は JSM 7001FA (日本電子製)，結晶方位解析システムは OIM Data collection(TSLソリューションズ製)を用いた.

\section{4. 圧粉磁芯の特性評価結果}

原料鉄粉の円形度と成形まま磁芯の密度との関係を Fig. 4 に示す，密度は磁芯の寸法と質量より算出した。密度は円形

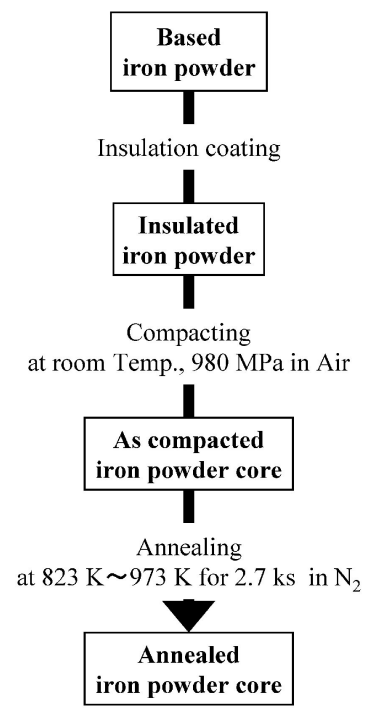

Fig. 3 Preparation process of the iron powder cores.

Table 3 Evaluated properties.

\begin{tabular}{|c|c|c|c|c|c|}
\hline & $\begin{array}{l}\text { DC magnetic } \\
\text { properties }\end{array}$ & $\begin{array}{l}\text { Mcrostructural } \\
\text { observation }\end{array}$ & $\begin{array}{l}\text { Measurement of } \\
\text { crystal grain size }\end{array}$ & $\begin{array}{l}\text { Micro-Vikers } \\
\text { hardness }\end{array}$ & $\begin{array}{c}\text { Crystal } \\
\text { oriantation }\end{array}$ \\
\hline Based iron powders & - & $\bigcirc$ & $\bigcirc$ & $\bigcirc$ & - \\
\hline Iron powder cores (as compacted) & - & $\bigcirc$ & - & $\bigcirc$ & $\bigcirc$ \\
\hline Iron powder cores (annealed at $973 \mathrm{~K}$ ) & $\bigcirc$ & $\bigcirc$ & $\bigcirc$ & $\bigcirc$ & $\bigcirc$ \\
\hline
\end{tabular}

$\bigcirc$ : Evaluated -: Un-evaluated 
度によらず $7.40 \pm 0.02 \mathrm{Mg} \mathrm{m}^{-3}$ でほぼ同一である．後続の 熱処理では $823 \mathrm{~K}$ および $973 \mathrm{~K}$ いずれの場合も磁芯の膨 張，収縮はほとんどなく，これらの密度は熱処理後磁芯の密 度とみなすことができる．原料鉄粉の円形度と熱処理後磁芯 の保磁力の関係を Fig. 5 に示す. 保磁力の測定回数は 1 試 料あたり 1 回である.973 K 熱処理後磁芯では原料鉄粉の円 形度が高いほど保磁力が低い傾向にあるが，823 K 熱処理後 磁芯では鉄粉の円形度 0.77 の原料鉄粉 B によるものが保磁 力は最大である。一方，原料鉄粉が同一の比較では，熱処理 温度が高いほど保磁力が低くなった。

Fig. 6 には $823 \mathrm{~K}$ および $973 \mathrm{~K}$ で処理した熱処理後磁芯 の光学顕微鏡写真を示す．腐食により鉄粉内部の結晶粒界が

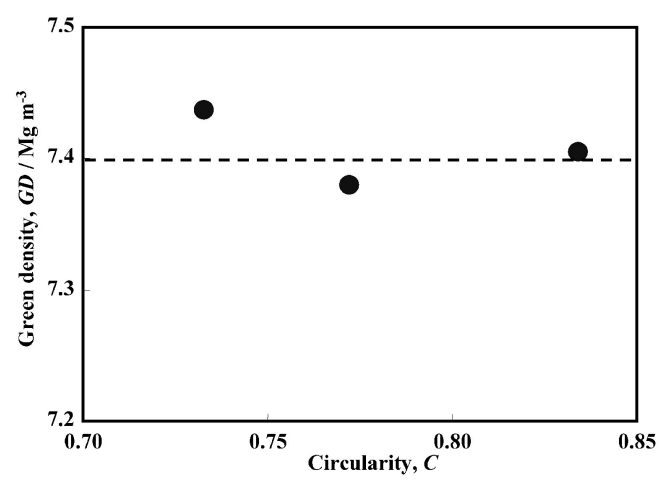

Fig. 4 Relationship between particle circularity and green density of the as compacted iron powder cores.

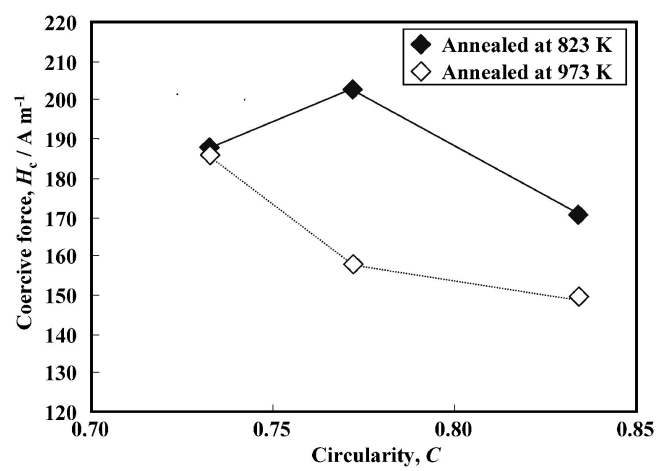

Fig. 5 Relationship between particle circularity and coercive force of the annealed iron powder cores.

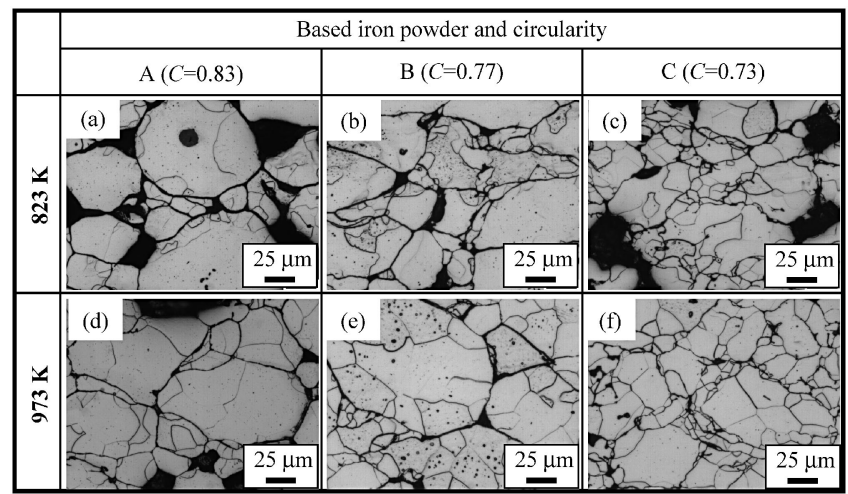

Fig. 6 Optical micrographs of the iron powder cores annealed at $823 \mathrm{~K}$ and $973 \mathrm{~K}$.
確認された. Fig. 6 の写真から切断法により結晶粒径を測定 した結果を，原料鉄粉の結晶粒径測定結果と併せて Fig. 7 にそれぞれ示す．なお，成形まま磁芯の断面は加工歪の影響 で結晶粒界の判別が困難であったため, 測定を断念した。い ずれの原料鉄粉も結晶粒径は $40 \mu \mathrm{m}$ 程度であるが，熱処理 後磁芯の結晶粒径はそれぞれの原料鉄粉より小さい。さら に，いずれの熱処理磁芯も，原料鉄粉の円形度の増加に伴い 結晶粒が粗大化する傾向を示した。

Fig. 8 には SEM/EBSD 解析結果から得た成形まま磁芯お よび熱処理後磁芯の断面の KAM マップを示す。成形まま 磁芯は，原料鉄粉が $\mathrm{A} \sim \mathrm{C}$ のいずれであっても鉄粉粒子表層 ほど KAM 值が高く，これは粒子表層ほど歪が大きいこと を示す．熱処理により KAM 值は減少し，973 K 熱処理後磁 芯はいずれも KAM 值がほぼ 0 であった. $823 \mathrm{~K}$ 熱処理後磁 芯は粒子中央に KAM 值の高い領域が残留しているが，原 料鉄粉 Cで作製したものは他の 2 つに比べて KAM 值が 0 に近い值まで減少した。

Fig. 9 には原料鉄粉の円形度と原料鉄粉抢よび各種磁芯の

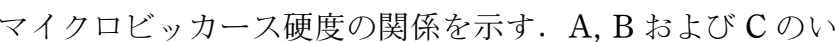
ずれを原料鉄粉としても，成形まま磁芯の硬度は原料鉄粉よ り高く, 熱処理後磁芯の硬度は成形まま磁芯よりも低くなっ た。 なた，熱処理温度が高い熱処理後磁芯ほど硬度は低下し た

\section{5. 考察}

\section{1 圧粉磁芯の結晶粒径と原料鉄粉粒子円形度の関係}

熱処理後磁芯の結晶粒径は，Fig. 7 に示すようにすべて原 料鉄粉の結晶粒径より小さくなっていた。 なた，原料鉄粉 A からなる成形まま磁芯および $823 \mathrm{~K}$ 熱処理後磁芯の KAM マップを Fig. 10 に示すが，成形ままでは粒子表面付近の KAM 值が高く，823 K 熱処理後磁芯では粒子表層に KAM 值が小さい粒径約 5 20 $\mu \mathrm{m}$ 程度の結晶粒が生成している. これは，原料鉄粉の結晶粒径約 $40 \mu \mathrm{m}$ より小さい。上記の 2 点は成形時に大きく歪んだ粒子表層部を起点として, 熱処 理により再結晶が起こっていること, さらには再結晶により 熱処理後の結晶粒径が微細化していることを示唆する.

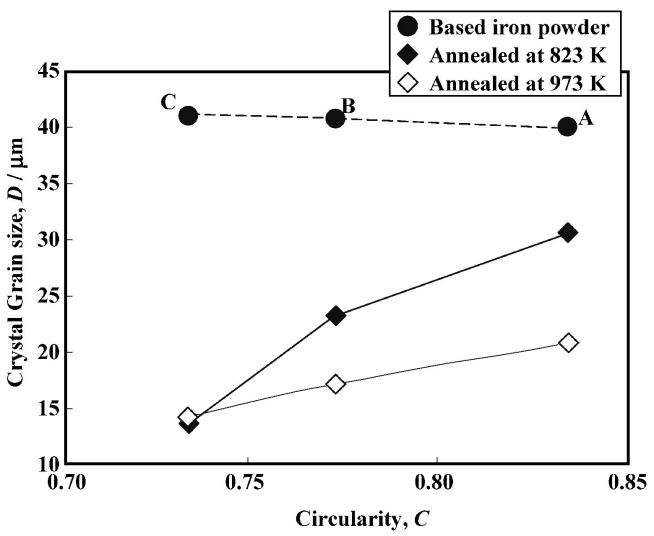

Fig. 7 Relationship between particle circularity and crystal grain size of the annealed iron powder cores. 


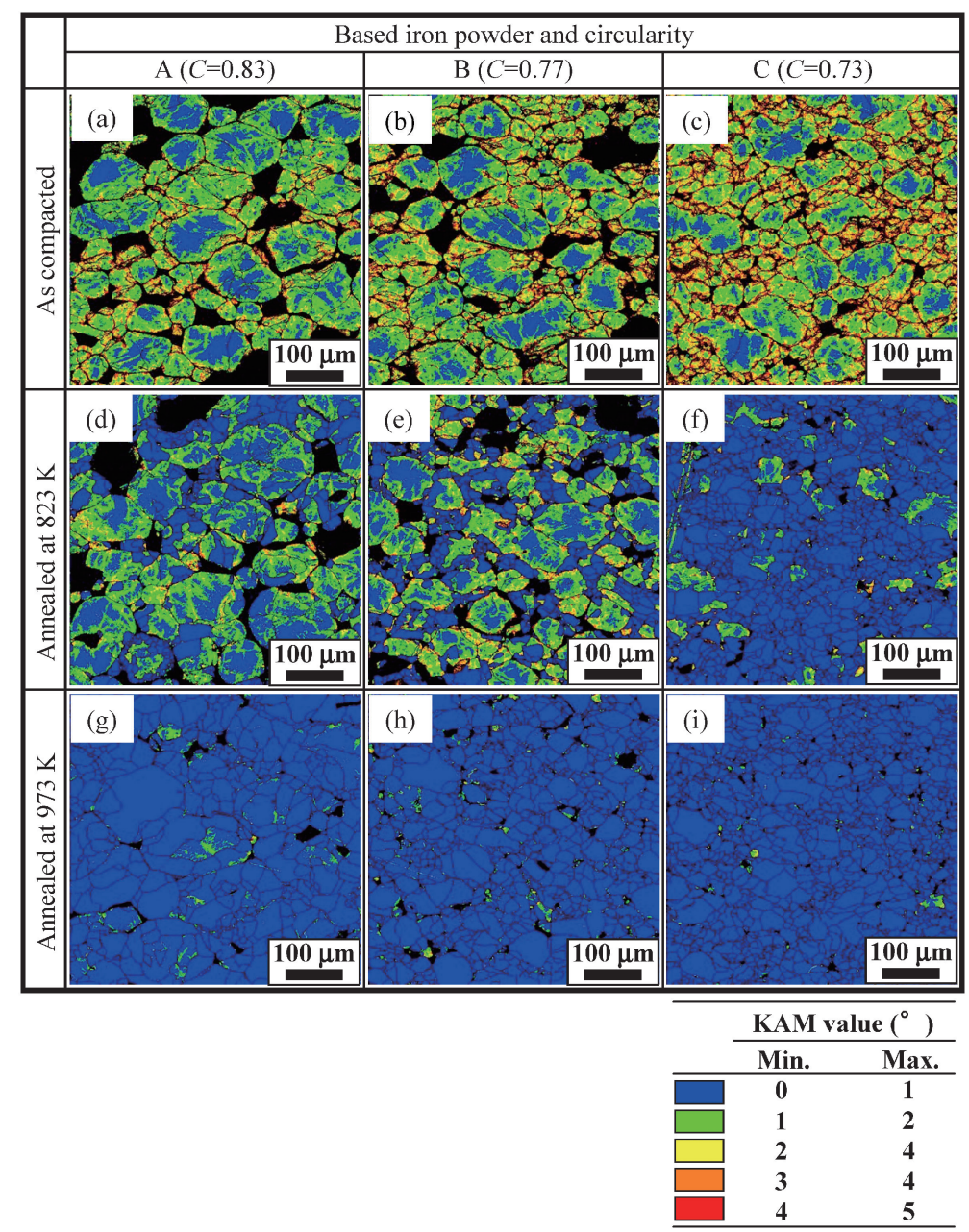

Fig. 8 KAM maps of the iron powder cores.

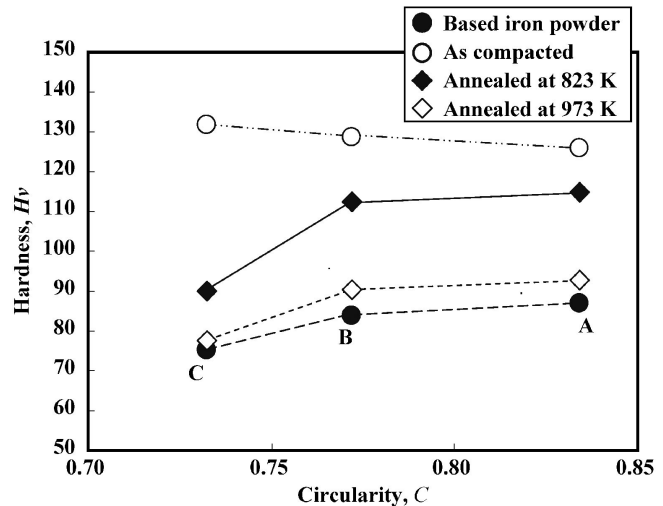

Fig. 9 Particle circularity dependence of the hardness of the based iron powders and iron powder cores.

$973 \mathrm{~K}$ 熱処理後磁芯に着目すると, 原料鉄粉の円形度が大 きいほど, 結晶粒径は大きくなる傾向にあることが分かり, 上記の再結晶が大きく関係していることが示唆される. 以下 では原料粉末の円形度が熱処理後磁芯中の結晶粒径に及ぼす 影響を解明するため, 成形時に蓄積される歪と, それに起因 する熱処理時の再結晶粒径の関係を定量的に考察する。な お, 絶縁被覆のシリコーン樹脂は $873 \mathrm{~K}$ まで加熱すると構 造が变化し，樹脂中の $\mathrm{Si}$ および $\mathrm{O}$ については, $\mathrm{Si}-\mathrm{O}$ 系の 化合物を生成する ${ }^{2)}$ 。 たた，樹脂中の C については，973 K
では浸炭は起こらないとの知見がある13〜15).したがって， これらの元素が鋼中に拡散し再結晶挙動に及ぼす影響は小さ いと考えられる.

まず，歪の指標として圧縮成形によって蓄積された転位密 度を見積もる. Bailey と Hirsch ${ }^{16)}$ は転位密度 $\rho$ と転位強化 による降伏応力の上昇量 $\Delta \sigma$ との関係を以下のように与えて いる.

$$
\Delta \sigma=\alpha G b \sqrt{\rho}
$$

ここで， $G$ および $b$ は，それぞれ剛性率(純鉄の場合 80 $\left.\mathrm{GPa}{ }^{17)}\right)$ 抢よびバーガースベクトル(純鉄の場合 $2.5 \times 10^{-10}$ $\left.\mathrm{m}^{18)}\right)$ である。 $\alpha$ は転位の線張力係数や転位の分布に依存す る定数であり, 中島ら ${ }^{19)}$ が純鉄での検討結果として示した 0.6 を用いることとした。

鉄粉粒子の $\Delta \sigma$ を引張試験等により直接的に求めることは 困難である.そこで, 次式で示されるビッカース硬度と降伏 応力の近似関係20)を用いることとした.

$$
\sigma \approx 3 H v
$$

ここで式（３）の全微分を行うことにより $\Delta \sigma$ を次式で定義し た.

$$
\Delta \sigma \approx 3 \Delta H v
$$

さらに, 式 ( 2 )に式 $(4)$ を代入し整理することで $\Delta H v$ から 転位密度を近似的に見積もる式 $(5)$ が得られる.

$$
\rho=(3 \Delta H v / \alpha G b)^{2}
$$




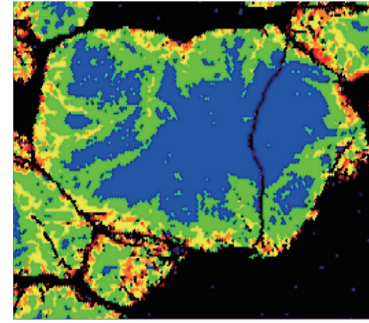

(a)As compacted

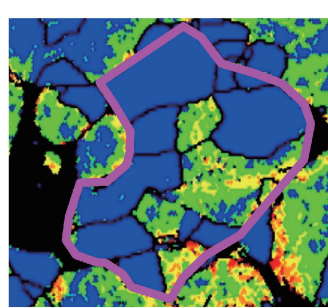

(b) Core annealed at

\begin{tabular}{|c|c|}
\hline \multicolumn{2}{|c|}{ KAM value $\left(^{\circ}\right.$ ) } \\
\hline Min. & Max. \\
\hline 0 & 1 \\
\hline 1 & 2 \\
\hline 2 & 4 \\
\hline 3 & 4 \\
\hline 4 & 5 \\
\hline
\end{tabular}

$25 \mu \mathrm{m}$

$823 \mathrm{~K}$

Fig. 10 Magnified KAM maps of iron powder cores with based iron powder A.

本研究において，各原料鉄粉はすべて同一の加工熱処理履歴 を経ており，初期歪は同等であると考えられる。したがって， Fig. 9 より, $\Delta H v$ は原料鉄粉の硬度と成形まま磁芯あるい は熱処理後磁芯との硬度差として求められ，それぞれ圧縮成 形時に導入される転位密度と熱処理後磁芯と熱処理後に残留 している転位密度を求めることができる.

原料粉末の粒子円形度と, Fig. 9 より算出した $\Delta H v$ を式 (5)に代入することで求めた近似的転位密度 $\rho$ の関係を Fig. 11 に示す. 円形度の低下に伴い転位密度が増加する傾 向にあることが分かる，また，熱処理により転位密度は減少 して抢り，同一の原料鉄粉からなる熱処理後磁芯では，熱処 理温度が高い磁芯の方が転位密度は小さかった。

次に円形度の低下により圧縮成形時に蓄積される転位密度 が増加する理由について，鉄粉充填層の圧密モデルに基づい て，原料鉄粉の円形度と粒子の塑性变形量との関係を考察す る.

著者ら ${ }^{21)}$ にれば, 圧縮成形中の鉄粉の充填密度増加機 構は成形初期に起こる「粒子の再配列」と成形後期に起こる 「粒子の塑性変形」の 2 つ分けられ, 成形中の充填密度増加 に及ぼす両者の寄与率は以下のように分離できる.

$$
[V(0)-V(p)] / V(0)=a_{1} \cdot \exp \left(-b_{1} / p\right)+a_{2} \cdot \exp \left(-b_{2} / p\right)
$$

ここで, $V(0)$ は圧縮前の粉末中の空隙率, $V(p)$ は任意の圧 縮圧力 $p$ での圧粉体中の空隙率であり, 左辺は圧縮に伴う空 隙率の減少率を表し, 右辺の第 1 項および第 2 項はそれぞ れ空隙率の減少に対する「粒子の再配列」および「粒子の塑 性変形」の寄与を示す。 また， $a_{1}, b_{1}, a_{2}$ ，および $b_{2}$ は粉末 の組成，見掛密度抢よび圧縮成形条件に依存する圧密パラ メーターである。

原料鉄粉の見掛密度 $A D$, 成形圧力 $p$ に打和成形体密度 $G D$ および真密度 $G D_{\mathrm{T}}$ を用いると, 式 $(6)$ は以下のように 書き換えることができる.

$$
\begin{aligned}
& G D-A D=\left(G D_{\mathrm{T}}-A D\right) \cdot\left[a_{1} \cdot \exp \left(-b_{1} / p\right)\right. \\
& \left.+a_{2} \cdot \exp \left(-b_{2} / p\right)\right]=\Delta G D_{\mathrm{r}}+\Delta G D_{\mathrm{p}}
\end{aligned}
$$

ここで, 式 ( 7 ) 左辺は圧縮成形開始から終了に至るまでの 密度上昇量を表し，右辺第 1 項が「粒子の再配列」による 密度上昇量 $\Delta G D_{\mathrm{r}}$, 右辺第 2 項が「粒子の塑性変形」による 密度上昇量 $\Delta G D_{\mathrm{p}}$ に相当する.

以下の解析では $G D_{\mathrm{T}}$ として純鉄の真密度 $7.87 \mathrm{Mg} \mathrm{m}^{-3}$ を 用いた．圧密パラメーター $a_{1}, b_{1}, a_{2}$ および $b_{2}$ は，本実験と

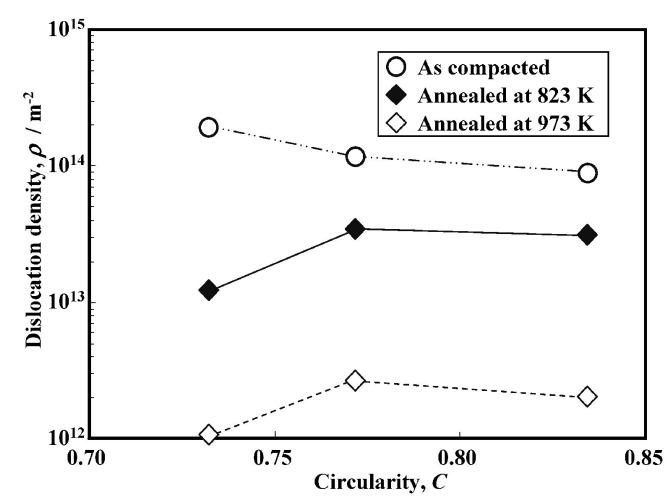

Fig. 11 Relationship between particle circularity and the dis-

\begin{tabular}{|c|c|c|c|c|c|c|}
\hline \multirow{2}{*}{$\begin{array}{l}\text { Based } \\
\text { iron } \\
\text { powder }\end{array}$} & \multirow{2}{*}{$\begin{array}{c}\text { Apparent } \\
\text { density, } \\
A D / \mathrm{Mg} \mathrm{m}^{-3}\end{array}$} & \multicolumn{4}{|c|}{ Parameters } & \multirow{2}{*}{ Remark } \\
\hline & & $a_{1}$ & $b_{1}$ & $a_{2}$ & $b_{2}$ & \\
\hline - & 3.07 & 0.333 & 17.8 & 0.766 & 226 & \multirow{2}{*}{ Ref. 21) } \\
\hline - & 3.95 & 0.343 & 19.6 & 0.794 & 247 & \\
\hline $\mathrm{A}$ & 4.07 & 0.344 & 19.9 & 0.798 & 250 & \multirow{3}{*}{$\begin{array}{l}\text { Calculated } \\
\text { from } \\
\text { regression }\end{array}$} \\
\hline B & 3.57 & 0.339 & 18.8 & 0.782 & 238 & \\
\hline $\mathrm{C}$ & 3.19 & 0.334 & 18.0 & 0.769 & 228 & \\
\hline
\end{tabular}
location density within the iron powder cores.

Table 4 Parameters for the compaction model.

同一の組成および同一条件で成形を行った文献 21) に着目し て求めた．先に述べたと抢りこれらのパラメーターは，粉末 の組成，見掛密度および圧縮成形条件に依存する．本実験な らびに文献 21) では組成および圧縮成形条件が同一であるた め, パラメーターは見掛密度のみに依存する。 そこで, 各パ ラメーターを見掛密度の関数として, 直線回帰式を作成し, 本実験に打ける原料鉄粉の見掛密度を代入することにより, 各々の原料鉄粉の圧密パラメーターを求めた. Table 4 にこ れらの圧密パラメーターを示す.

Table 4 の数值，各原料鉄粉の見掛密度抢よび成形圧力 $980 \mathrm{MPa}$ を用いて式 ( 7 ) 第 2 項より算出した「粒子の塑性 変形」による密度上昇量 $\Delta G D_{\mathrm{p}}$ を, 粒子円形度に対してプ ロットした結果を Fig. 12 に示す.これより，原料鉄粉の円 形度の上昇により $\Delta G D_{\mathrm{p}}$ が小さくなることが分かる.この 原因は, 円形度の上昇が「粒子の再配列」を容易にし, 圧縮 成形による密度上昇量に占める「粒子の再配列」による密度 上昇量 $\Delta G D_{\mathrm{r}}$ の割合が増加したためであると考えられる. 


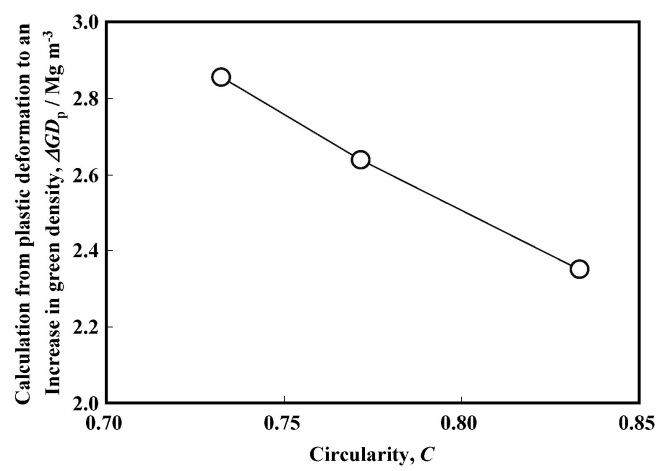

Fig. 12 Relationship between particle circularity and calculation from plastic deformation of the iron powder particles to an increase in green density.

$\Delta G D_{\mathrm{p}}$ には絶縁被覆の影響も含まれている．原料鉄粉 $\mathrm{A} \sim$ C は粒子球状度が異なるので比表面積も異なる。したがっ て，等量の絶縁被覆では層厚が異なる。しかしながら，絶縁 被覆の密度と粒度分布より，鉄粉を球近似した場合でも絶縁 被覆の膜厚は $0.2 \mu \mathrm{m}$ となる.これは，鉄粉の平均粒子径 80 $\mu \mathrm{m}$ に対して 2 析以上小さい. 実際の原料鉄粉 $\mathrm{A} \sim \mathrm{C}$ は球近 似した場合よりも比表面積が大きくなるため, 膜厚はさらに 薄くなると考えられる．このことから，膜厚の変化による $\Delta G D_{\mathrm{p}}$ への影響は無視できるとして考察を続ける。

本項の終わりに「粒子の塑性変形」によって蓄積された歪 エネルギーと熱処理後の結晶粒径の関係について考察する.

圧粉磁芯中の歪抢よび歪エネルギーは以下の手順で求めた.

まず，压縮成形を単軸圧縮とみなすと，「粒子の塑性変形」 による歪 $\varepsilon_{\mathrm{p}}$ は以下のように与えられる(Appendix 参照).

$$
\varepsilon_{\mathrm{p}}=\Delta G D_{\mathrm{p}} / G D
$$

上で求めた $\Delta G D_{\mathrm{p}}$ と式 $(8)$ を用いて算出した歪を Table 5 に示す.

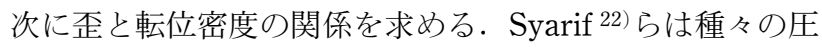
下率の純鉄冷延の転位密度を測定している。この報告に抢け

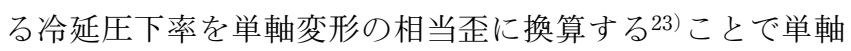
圧縮による歪と転位密度の関係を見積もった。「粒子の塑性 変形」による歪から推定した転位密度は最小值が $1.4 \times 10^{14}$ $\mathrm{m}^{-1}$ であり, 最大值が $1.9 \times 10^{14} \mathrm{~m}^{-1}$ であった. 硬度差から 算出した転位密度は最小值が $9.3 \times 10^{13} \mathrm{~m}^{-1}$, 最大值が 2.0 $\times 10^{14} \mathrm{~m}^{-1}$ であったので, どちらの手法で算出した転位密 度も $10^{13} \sim 10^{14} \mathrm{~m}^{-1}$ のオーダーで一致している。これよ り, 円形度の増加による成形末ま磁芯中の転位密度の減少 は, 成形中の鉄粉の塑性変形量の減少によって説明できる.

再結晶は熱処理による歪エネルギーの解放であるため, 熱 処理の結晶粒径と関連付けて考えるために, 式 ( 9$)^{24)}$ を用 いて転位密度 $\rho$ を歪エネルギー $E_{\mathrm{D}}$ に置き換える。

$$
E_{\mathrm{D}}=\rho G b^{2} / 2
$$

上式に $\Delta H v$ より求めた $\rho$ を代入して $E_{\mathrm{D}}$ を計算した結果を Fig. 13 に示す. 成形まま磁芯の歪エネルギーに着目する と, 円形度が 0.73 から 0.83 へ増加するに伴い, 蓄積されて いる歪エネルギーが約 $1 / 2$ まで減少していることが分かっ た. $973 \mathrm{~K}$ 熱処理後磁芯の歪エネルギーは円形度によらずほ ぼゼロに近い値となっていた。これは熱処理により歪が十分
Table 5 Strain values estimated from eq. (8).

\begin{tabular}{cc}
\hline Based iron powder & Strain induced by plastic deformation of iron powder, $\varepsilon_{\mathrm{p}}$ \\
\hline A & 0.31 \\
B & 0.35 \\
C & 0.38 \\
\hline
\end{tabular}

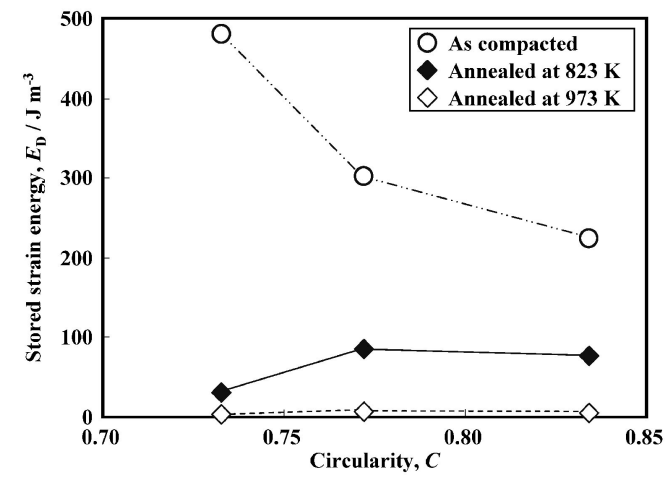

Fig. 13 Relationship between the particle circularity and the strain energy stored in iron powder cores.

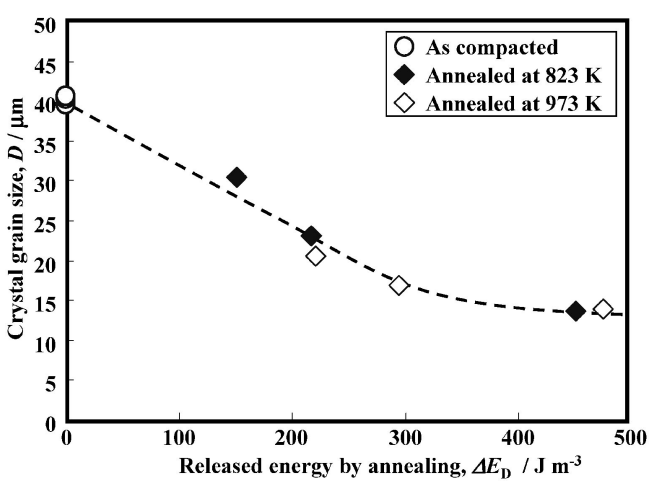

Fig. 14 Relationship between the energy released by annealing and crystal grain size in the iron powder cores. (The dashed line is a guide to eye.)

に開放されたことを示している. 一方, $823 \mathrm{~K}$ 熱処理後磁芯 の歪エネルギーは成形まま磁芯と $973 \mathrm{~K}$ 熱処理後磁芯の中 間の值となって抢り，歪の残留が確認された。

成形まま磁芯に蓄積された歪エネルギーと, 熱処理後磁芯 に残留する歪エネルギーの差分を熱処理によって開放された 歪エネルギー $\Delta E_{\mathrm{D}}$ とみなす。これは, 再結晶による歪エネ ルギー解放量と, 再結晶の前段階で起こる回復による歪エネ ルギー解放量の和である. $\Delta E_{\mathrm{D}}$ と熱処理後の結晶粒径との 関係を求めたものを Fig. 14 に示す。な㧍, 成形まま磁芯の 結晶粒径は, 前述のと打り原料鉄粉の結晶粒径と同一とし た. 結晶粒径は原料鉄粉の種類や熱処理温度によらず, $\Delta E_{\mathrm{D}}$ の増加に伴い減少する傾向を示した。したがって, 圧縮成形 により蓄積される歪エネルギーが大きいほど, 磁芯鉄粉粒子 中の転位密度が高く, その結果熱処理中の再結晶核形成サイ 卜が増加し, 熱処理後の結晶粒径は小さくなると説明され る. また, 上述のように $\Delta E_{\mathrm{D}}$ は再結晶核生成数によって決 まる熱処理後の結晶粒径によって整理できることから, 本実 験においては回復による歪エネルギーの開放はすべての試料 
で同等であるか，極めて小さいと考えられる.

以上の検討から，原料鉄粉の粒子円形度増加は圧縮成形時 の「粒子の塑性変形」を減少させ, これにより圧粉磁芯に蓄 積される歪エネルギーが減少し, 熱処理後の結晶粒径は粗大 化すると結論付けられる.

\section{2 圧粉磁芯の保磁力に及ぼす原料鉄粉粒子円形度の影響}

磁性体が磁壁の移動によって磁化する場合, 保磁力 $H_{\mathrm{c}}$ は 磁性体の結晶磁気異方性や磁壁のピンニングサイトの量など によって変化する．このうち, 磁壁のピンニングサイトとし ては, 結晶粒界, 介在物および歪が考えられる. Pfeifer ら ${ }^{25)}$ によれば，これら 3 つの゚ンンニングサイトの寄与は下 式のように分離できる.

$$
H_{\mathrm{c}}=H_{\mathrm{ck}}+H_{\mathrm{c} \_\mathrm{ex}}
$$

ここで， $H_{\mathrm{ck}}$ は結晶粒界に起因する保磁力， $H_{\mathrm{c} \_\mathrm{ex}}$ は介在物 および歪に起因する保磁力である。このうち， $H_{\mathrm{ck}}$ について は Mager 26)らによって結晶粒径との関係が求められて抢り,

$$
H_{\mathrm{ck}} \approx(3 \cdot \gamma) /\left(J_{\mathrm{s}} \cdot D\right)
$$

となる、ここで， $\gamma$ は磁壁エネルギー， $J_{\mathrm{s}}$ は飽和磁化， $D$ は 結晶粒径である. Pfeifer ら 25$)$ のi-Feに打ける検討, Herzer ${ }^{27)}$ らの Fe-Si における検討, R. H. Yu ら ${ }^{28)}$ の Co-Fe に㧍ける検討で式(11)が実験結果と良い一致を示したと報 告されている.

磁壁エネルギーの理論值は,

$$
\gamma=a \sqrt{A \cdot K}
$$

で与えられる29).ここで， $A$ は交換スティフネス係数， $K$ は磁気異方性定数, $a$ は磁壁の種類によって決まる定数であ る.

純鉄の場合, $A=1.49 \times 10^{-11} \mathrm{~J} \mathrm{~m}^{-130)}, K=4.72 \times 10^{4}$ $\mathrm{J} \mathrm{m}^{-331)}$, である. また, 純鉄の磁化容易磁区は $[100]$ 方向 である。[100]方向に磁化した場合の磁壁は $90^{\circ}$ 磁壁および $180^{\circ}$ 磁壁の 2 種類であり，その時の $a$ の值は 1 および 2 と なる ${ }^{29)}$ 。これらの值から磁壁エネルギーを計算すると, $90^{\circ}$ 磁壁エネルギー $\gamma_{90^{\circ}}=8.4 \times 10^{-3} \mathrm{~J} \mathrm{~m}^{-2}$ で, $180^{\circ}$ 磁壁エネ ルギー $\gamma_{180^{\circ}}=1.7 \times 10^{-3} \mathrm{~J} \mathrm{~m}^{-2}$ となる. 実際の鉄の組織中に は $90^{\circ}$ 磁壁と $180^{\circ}$ 磁壁が混在していると考えられる ${ }^{32)}$. し たがって，これらの磁壁が複合的に移動して磁化が起こると 考えると磁壁エネルギーは $\gamma=8.4 \sim 1.7 \times 10^{-3} \mathrm{~J} \mathrm{~m}^{-2}$ の範囲 内となると考えられる．

一方，式(11)を式(10)に代入すると，

$$
H_{\mathrm{c}}=S / D+H_{\mathrm{c} \_ \text {ex }}
$$

となるここで，

$$
S=(3 \cdot \gamma) / J_{\mathrm{s}}
$$

である。したがって，

$$
\gamma=\left(S \cdot J_{\mathrm{s}}\right) / 3
$$

となる。したがって, 結晶粒界以外の要因(介在物, 歪)によ る保磁力 $H_{\mathrm{c} \_ \text {ex }}$ を定数と仮定すれば, $H_{\mathrm{c}}$ は $1 / D$ に対して直 線的に変化し，その傾き $S$ から，磁壁エネルギー $\gamma$ を計算 できる。

Fig. 13 で明らかなように, $973 \mathrm{~K}$ 熱処理後磁芯は原料鉄 粉によらず歪の指標である歪エネルギーの值がほぼ等しい. 原料粉の不純物レベルもほぼ同等であるので, 結晶粒界以外

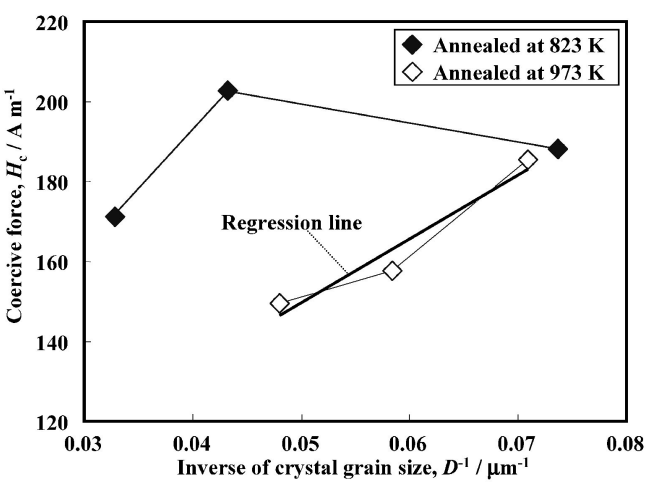

Fig. 15 Relationship between inverse of crystal grain size and coercive force.

の要因 (介在物, 歪)による保磁力 $H_{\mathrm{c} \_\mathrm{ex}}$ を定数とみなせる. 実際，文献 7)では不純物量と保磁力との関係が議論されて いるが，文献中の不純物量と保磁力の関係から，原料鉄粉 $\mathrm{A} \sim \mathrm{C}$ に打ける不純物量差による保磁力差を見積もったとこ ろ, その変動は高々 $3 \%$ であった. そこで, 以下ではこのシ リーズについて，上述の仮定の下で考察を進める.

Fig. 15 には熱処理後磁芯の結晶粒径の逆数と保磁力実測 值との関係を示す. $973 \mathrm{~K}$ 熱処理後磁芯の保磁力は結晶粒径 の逆数に対して直線的に变化し, 回帰式を求めると $H_{\mathrm{c}}=$ $1.59 \times 10^{3} / D+70.9$ となる. また, 直線の傾きと鉄の飽和磁 化 $\left.J_{\mathrm{s}}=2.16 \mathrm{~T}^{33}\right)$ から式 (15)の関係により, $\gamma=1.2 \times 10^{3}$ $\mathrm{J} \mathrm{m}^{-2}$ と算出される.これは前述した $\gamma$ の理論值の範囲内に あり， $90^{\circ}$ 磁壁と $180^{\circ}$ 磁壁エネルギーの中間程度の值であ る.したがって $973 \mathrm{~K}$ で熱処理されたシリーズの $H_{\mathrm{c}}$ と $1 / D$ の関係は式 (13)で $H_{\text {c_ex }}$ が定数としたモデルで説明でき, $90^{\circ}$ 磁壁と $180^{\circ}$ 磁壁の移動が同じ程度起こっていると考えら れる.

なお，Fig. 15 には $823 \mathrm{~K}$ 熱処理後磁芯の $H_{\mathrm{c}}$ も示したが， $1 / D$ に対して直線的に変化していない。このシリーズは Fig. 13 から明らかなように, 磁芯中に歪の残留があり, 式 (13)中の $H_{\mathrm{c} \_\mathrm{ex}}$ 一定の仮定が成立していないためと考えられ る.

以上のことから，圧粉磁芯中に蓄積された歪が十分開放さ れた条件では, 保磁力 $H_{\mathrm{c}}$ の変化は結晶粒径の変化で説明で きる．さらに，円形度が増加することにより結晶粒が粗大化 していたことから, 円形度の増加は結晶粒の粗大化を通して 保磁力を低減する効果があると考えられる.

\section{6. 結 言}

本研究では圧粉磁芯の保磁力低減の指針を得るため, 原料 鉄粉の粒子形状が圧粉磁芯の微細組織および磁気特性に及ぼ す影響を検討し，以下の知見を得た。

（1）原料鉄粉の粒子円形度が高くなるに従って, 熱処理後 磁芯の結晶粒径が粗大化する.

（2）成形中に鉄粉表層が塑性変形し，成形後の熱処理によ って塑性変形していた鉄粉表層から再結晶粒が生成する.

（3）原料鉄粉の円形度が高くなるにつれて，成形中に鉄粉 
に蓄積される歪エネルギーが減少する.

（4）これは，鉄粉の円形度が高くなることで，同じ密度に 成形しても『粒子の塑性変形』による密度上昇の寄与が減少 するためである.

（5）歪エネルギー低減の作用により，再結晶核の生成が抑 制されることが(1)の結果につながる.

（6）熱処理温度が $973 \mathrm{~K}$ の場合，原料鉄粉の円形度が高 くなるにつれて熱処理後磁芯の保磁力が減少する.

(7) 蓄積された歪エネルギーが同等の圧粉磁芯 $(973 \mathrm{~K}$ 熱 処理後磁芯)の保磁力は結晶粒径の逆数に比例するモデルと 挙動が一致する.

（8）原料鉄粉の円形度が高くなるにつれて，熱処理後磁芯 の結晶粒径が粗大化するため保磁力は低減する.

\section{文献}

1) K. Sadahiro, S. Gotoh and S. Uenosono: JFE Tech. Rep. 8 (2005) 1-6.

2) M. Sugiyama, T. Yamaguchi, T. Ohkouchi, H. Kishimoto, T. Hattori and T. Saito: Sokeizai 51(2010) 24-29.

3) H. Mitani, A. Hanaki, H. Yaguchi and Y. Seki: Kobe Steel Eng. Rep. 48(1998) 25-28.

4) S. Takemoto: Denki Seiko 82(2011) 57-65.

5) T. Ishimine, A. Watanabe, T. Ueno, T. Maeda and T. Tokuoka: SEI Tech. Rev. 72(2011) 117-123.

6) S. Takajo: Doctorial Theses (Tohoku University, 1986).

7) T. Tokuoka, T. Maeda and T. Ishimine: Sokeizai 52(2011) 1118.

8) H. Hojo, N. Akagi, T. Sawayama and H. Mitani: Kobe Steel Eng. Rep. 60(2010) 79-83.

9) T. Maeda, A. Sato, Y. Mochida, H. Toyoda, K. Mimura and T. Nishioka: Proc. Powder Metallurgy World Congress, (Korean Powder Metallurgy Inst., 2006) pp. 1284-1285.

10) R. L. Fullman: Trans. AIME (1953) 197-447.

11) The Japan society of Powder and Powder Metallurgy: FuntaiFunmatsuyakinyougojiten, (Nikkan Kogyo Shinbun, 2001) p. 541.

12) K. Sasaki, M. Kamaya, T. Miura and K. Fukuya: J. Japan Inst. Metals 74(2010) 467-474.

13) X. Zhang, R. Takahashi, T. Akiyama and J. Yagi: Tetsu-toHagane 83(1997) 299-304.

14) T. Kameoka and T. Kimura: J. Jpn. Soc. Powder Powder Metal. 19 (1973) 281-285.

15) H. Mitani, K. Majima and Y. Hanatate: J. Japan Inst. Metals 39 (1975) 168-174.

16) J. E. Bailey and P. B. Hirsch: Philos. Mag. 5(1960) 485-497.

17) W. C. Leslie: The Physical Metallurgy of Steel, (McGraw-Hill Kogakusha, 1982) p. 113.

18) W. C. Leslie: The Physical Metallurgy of Steel, (McGraw-Hill Kogakusha, 1982) p. 3.

19) K. Nakashima, Y. Fujimura, H. Matsubayashi, T. Tsuchiyama and S. Takaki: Tetsu-to-Hagane 93(2007) 459-465.

20) T. Yoshizawa and G. Kuroki: Jour. Jpn. Soc. Mech. Eng. 64 (1961) 1453-1460.

21) Y. Ozaki, T. Ono, T. Takamiya and S. Uenosono: J. Jpn. Soc. Powder Powder Metal. 58(2011) 83-90.

22) J. Syarif, K. Nakashima, T. Tsuchiyama and S. Takaki: Tetsuto-Hagane 91 (2005) 790-795.

23) The Iron and Steel Institute of Japan: Theory and Practice of Flat Rolling (Reverse edition), (The Iron and Steel Institute of Japan, 2010) p. 10
24) F. J. Humphrey and M. Hatherly: Recrystallization and related phenomena, (Elsevier, 2004) p. 18.

25) F. Pfeifer and C. Radeloff: J. Magn. Magn. Mater. 19(1980) 190-207.

26) A. Mager: Annalen der Physik. 6 (1952) 15-16.

27) G. Herzer: IEEE Trans. Magn. 26 (1990) 1397-1402.

28) R. H. Yu, S. Basu, Y. Zhang, A. Parvizi-Majidi and John Q. Xiao: J. Appl. Phys. 85(1999) 6655-6659.

29) K. Ohta: Jikikougakunokiso II, (Kyoritsu Shuppan, 1973) pp. $272-273$.

30) S. chikazumi: Kyojiseitainobutsuri (last volume), (Shokabo, 1984) p. 175.

31) S. chikazumi: Kyojiseitainobutsuri (last volume), (Shokabo, 1984) p. 4

32) K. Ohta: Jikikougakunokiso II, (Kyoritsu Shuppan, 1973) p. 268.

33) K. Ohta: Jikikougakunokiso II, (Kyoritsu Shuppan, 1973) p. 275.

\section{Appendix}

粉末圧縮成形の模式図を Fig. A1 に示す．粉末圧縮成形を 単軸圧縮とみなすと，その歪 $\varepsilon_{\mathrm{p}}$ は以下のように表すことが できる.

$$
\varepsilon_{\mathrm{p}}=\left(l-l_{\mathrm{p}}\right) / l
$$

ここで $l$ は圧縮成形前の粉末充填層厚， $l_{\mathrm{p}}$ は任意の成形圧力 での成形体厚さである。「粒子の塑性变形」による密度上昇 は「粒子の再配列」の後に起こる，そのため，「粒子の塑性 変形」のみによる歪は以下のように表すことができる.

$$
\varepsilon_{\mathrm{p}}=\left(l_{\mathrm{ip}}-l_{\mathrm{p}}\right) / l_{\mathrm{ip}}
$$

ここで， $l_{\mathrm{ip}}$ は塑性変形開始時の成形体厚さである．ここ で, 成形体の圧縮方向に垂直な断面積を $A^{\prime}$, 成形体の質量 をwとすると，式(A2)は以下のように書き換えることがで きる。

$\varepsilon_{\mathrm{p}}=\left(l_{\mathrm{ip}} \cdot A^{\prime}-l_{\mathrm{p}} \cdot A^{\prime}\right) /\left(l_{\mathrm{ip}} \cdot A^{\prime}\right)=\left(V_{\mathrm{ip}}-V_{\mathrm{p}}\right) / V_{\mathrm{ip}}$

$\varepsilon_{\mathrm{p}}=\left(V_{\mathrm{ip}} / w-V_{\mathrm{p}} / w\right) /\left(V_{\mathrm{ip}} / w\right)=\left(1 / G D_{\mathrm{ip}}-1 / G D\right) /\left(1 / G D_{\mathrm{ip}}\right)$

ここで，GD $\mathrm{ip}$ は「粒子の塑性変形」開始時の成形体密度で ある. 式(A3) はさらに以下のように変形することができ， 本文中の式 ( 8 ) が得られる.

$$
\begin{aligned}
\varepsilon_{\mathrm{p}} & =\left(1 / G D_{\text {ip }}-1 / G D\right) /\left(1 / G D_{\text {ip }}\right)=\left(G D-G D_{\text {ip }}\right) / G D \\
& =\Delta G D_{\mathrm{p}} / G D
\end{aligned}
$$

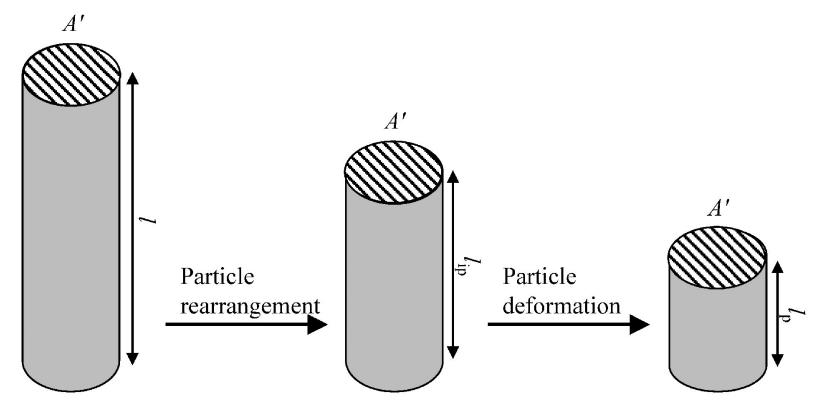

Fig. A1 Schema of compacting of iron powder. 